\title{
The Metaphysics of Human Freedom: From Kant's Transcendental Idealism to Schelling's Freiheitsschrift
}

\author{
Sebastian Gardner
}

'How must a world be constituted for a moral being?' ('Oldest System-Programme', 1796/97) ${ }^{1}$

\section{Schelling's 1809 Philosophical Investigations into the Essence of Human Freedom,} known as the Freiheitsschrift, marks a turning point in his development - the end of his attempt to define a satisfactory form of absolute idealism, and the beginning of his late philosophy, by any measure one of the most demanding parts of German Idealism. ${ }^{2}$ The treatise is short but its scope could hardly be broader. In addition to the one announced in its title, topics discussed in it include pantheism and philosophical systematicity, moral psychology, good and evil, the nature of God, identity and predication, and the nature of being. Schelling's treatment of these themes evidences a change of key, employing idioms and drawing on resources alien to the modern philosophical tradition, as if he were embarking on a new type of metaphysical speculation - making it no accident that Heidegger seized on the work and declared it the summit of German Idealism. $^{3}$

In this paper I make the case that Schelling's central claims in the Freiheitsschrift can be regarded as the product of a complex and extended development arising out of Kant's theory of freedom. This is not quite how Schelling presents it. As he describes the overall aim of the treatise, it is concerned with the problem, more easily recognized as attaching to Spinoza's legacy than to Kant's, of incorporating an adequate conception of human freedom within the system of philosophy, where system is understood to carry implications of completeness and finality. ${ }^{4}$ This is however, as I will try to show, fully compatible with interpreting Schelling as taking over where Kant leaves off, for it is precisely in their encounter with Spinozism that the limitations of Kant's metaphysics of freedom are revealed. Because I am approaching the Freiheitsschrift from a somewhat specific angle, my treatment of it here will not amount to a comprehensive view of the work, and many important ideas contained in it will not receive discussion, although they are not, I believe, inconsistent with the interpretation I offer. To root the speculative claims of the Freiheitsschrift in a Kantian problematic is of course not to contest the originality and autonomy of Schelling's thought: the guiding 
notion is rather that, if an argument can be constructed from broadly Kantian premises to Schellingian conclusions, then that is all to the good from the point of view of elucidating an undoubtedly profound but also very puzzling work, one which moreover may readily seem, particularly in Hegelian eyes, to be leading the post-Kantian development away from its rationalist core into wilder, Schopenhauerian and protoHeideggerean territory. The intention in short is to show that, whatever its ultimate degree of success, the Freiheitsschrift neither breaks with the original concerns of German Idealism nor leads it astray. ${ }^{5}$

\section{Kant's metaphysics of human freedom: the difficulty created for transcendental idealism by Spinozism}

I begin in this section with a selective and highly abbreviated account of Kant's theory of human freedom and the questions it raises, designed to show where Kant may be thought to leave matters for the purposes of the Freiheitsschrift.

According to Kant, although our freedom must be deemed in the final instance incomprehensible: 'reason would overstep all its bounds if it took it upon itself to explain how [...] freedom is possible'. ${ }^{6}$ What philosophy can nonetheless do is specify the conditions of free agency, and underwrite its incomprehensibility - there can be a metaphysical explanation of its resistance to rational insight, which at the same time reassures us of freedom's reality. The conditions Kant sets on free agency are fourfold. In order to act freely, it must be true that the agent could act (or could have acted) otherwise than she does (did). Second, the determining grounds of the action must lie within the agent's control or power, in meiner Gewalt. Third, their action must be determined not empirically but by reason. Fourth, the agent must be if not motivated then at least motivatable by pure practical reason, the moral law. And in order for these four conditions to be fulfilled, Kant argues, two metaphysical conditions have to be met. First, the agent must have the peculiar power of reflexive causality or spontaneous selfdetermination that Kant calls transcendental freedom, defined as 'an unconditioned causality which begins to act of itself'. Second, the agent and her action must have intelligible grounds: the action must be the product of intelligible causality issuing from the agent's intelligible character. Kant thinks that if transcendental idealism is assumed, and under no other condition, can these metaphysical conditions be fulfilled. ${ }^{7}$ 
Transcendental idealism is thus a condition for the justified attribution of freedom to human agents.

For present purposes all issues concerning the grounds and interconnections of these various claims, along with the pressing epistemological questions surrounding Kant's account, can be put aside. What I want to focus on is the particular metaphysical difficulty that critical discussion of Kant's theory of freedom in the very earliest years of Kant reception brought to light. The two central figures here are Carl Christian Erhard Schmid, and Karl Leonhard Reinhold. Both professed themselves Kantians, believed that Kant's teachings on freedom require clarification, and proceeded to rework Kant's theory. The conclusions they came to are however diametrically opposed. According to Schmid, the exercise of reason must be intelligibly determined, and the intelligible fatalism (as he calls it) which this entails represents a consistent and defensible position which Kantians should espouse. ${ }^{8}$ According to Reinhold, Kant's theory must be recast in terms of an irreducible power of self-determination, a capacity to bring about states of affairs by virtue of one's so choosing and nothing else - which Reinhold, following Kant, calls Willkür, the power of choice that sets the self in motion, as opposed to Wille, the power of practical reasoning by virtue of which one merely comes to know the moral properties of actions. ${ }^{9}$

Schmid's reasoning is simply that, if no intelligible causality governs human agency, then freedom is reduced to mere accident, Zufall, and its moral meaning is destroyed, whereas intelligible determinism, Schmid asserts, is sufficient for moral purposes, for it (at least) lifts us out of natural causality. Reinhold, quite reasonably doubtful that a deterministic supersensible realm can be considered any more hospitable to morality than a deterministic sensible realm, argues that freedom is a basic power distinct from the power of practical reasoning, independent of the other powers of the mind and not explicable in terms of any other more fundamental concept, and no more mysterious than the faculty of empirical knowledge: freedom is 'fully comprehensible', völlig begreiflich.

Plainly not both of these accounts can be correct as an interpretation of Kant. It is also clear where their respective weaknesses lie. As another contemporary, Christian Andreas Leonhard Creuzer, pointed out, the strength of each is the weakness of the other. ${ }^{10}$ Schmid's position satisfies theoretical reason but contradicts practical reason: if we fail to act morally because we cannot do so, then we cannot view our immoral acts as effects of our reason, or regard their opposites as real possibilities; so the concepts of 
guilt and merit fall away. Reinhold's position satisfies practical reason but is incoherent from the standpoint of theoretical reason, since it is absurd to postulate a cause which contains the sufficient basis for contradictorily opposed effects (a cause which is sufficient for the agent's doing A and also sufficient for the agent's doing not-A). So, Creuzer argues, advancing to a skeptical conclusion, the two views cancel one another out, and we are left with no reason to think that freedom is real, and every reason to think that it is a deception arising from our ignorance of the real causes of our actions.

That Kant's theory allowed itself to be pulled in two such contrary directions is of course remarkable, and leads us to ask what Kant himself made of these construals. We know what he thought of Reinhold from The Metaphysics of Morals, published several years after Reinhold's contribution, where Kant explicitly denies that the power of choice, Willkür, is the locus of our freedom. The concept of a power of free choice, freie Willkür, is not a primary but, he tells us, a derivative concept: it presupposes the objective legislation of Wille and signifies the mere possibility of failure to execute it. ${ }^{11}$ To treat it as primitive and independent, Kant asserts, is either to proceed from the empirical phenomenon of choice, as if transcendental freedom were merely abstracted therefrom, or it is to suppose, incorrectly, that we have insight into that power as a noumenal reality. Regarding Schmid's position, Kant does not address it directly and by name, but there is one place in his writings, in the Critique of Practical Reason, where he does confront head on the threat of intelligible fatalism. This is also, as I have said, the point where his use of transcendental idealism in the defence human freedom runs into difficulty. Here is the relevant passage:

But a difficulty still awaits freedom insofar as it is to be united with the mechanism of nature in a being that belongs to the sensible world, a difficulty which, even after all the foregoing has been agreed to, still threatens freedom with complete destruction [...] [I]f it is granted us that the intelligible subject can still be free with respect to a given action, although as a subject also belonging to the sensible world, he is mechanically conditioned with respect to the same action, it nevertheless seems that, as soon as one admits that God as universal original being is the cause also of the existence of substance (a proposition that can never be given up without also giving up the concept of God as the being of all beings and with it his all-sufficiency, on which everything depends), one must admit that a human being's actions have their determining ground in something altogether beyond his control, namely in the causality of a supreme being which is distinct from him and upon which his own existence and the entire determination of his causality absolutely depend. ${ }^{12}$ 
In such circumstances, Kant says, a human being 'would be a marionette or an automaton', 'built and wound up by the supreme artist; self-consciousness would indeed make him a thinking automaton, but the consciousness of his own spontaneity, if taken for freedom, would be mere delusion' - since, although the proximate determining causes of thought would be internal to the agent, 'the last and highest' cause would be 'found entirely in an alien hand'. Kant explicitly refers to the threat thereby posed as 'Spinozism'.'

The solution offered in the second Critique involves transcendental idealism once again, but deployed in a different way from the Third Antinomy of the first Critique. Were God the creator of beings in the sensible world, Kant tells us, then freedom would be annihilated; but appearances are the work of the human subject, whose forms of intuition are space and time. God thus cannot fix the facts in the realm of appearance:

[T] he concept of a creation does not belong to the sensible way of representing existence or causality but can only be referred to noumena. Consequently, if I say of beings in the sensible world that they are created, I so far regard them as noumena. Just as it would thus be a contradiction to say that God is a creator of appearances, so it is also a contradiction to say that as creator he is the cause of actions in the sensible world and thus of actions as appearances, even though he is the cause of the existence of the acting beings (as noumena). ${ }^{14}$

Human freedom is not itself an appearance, but human agency consists in a synthesis of practical reason with appearance, so if appearance falls outside the scope of divine determination, then so too does human agency. Insulating appearances from God's determining power thus makes human freedom possible. Transcendental idealism as invoked in response to Spinozism seeks to cut loose empirical reality metaphysically from things in themselves, the objects of intellectual intuition which compose Spinoza's ontology. Kant's argument is that, if things in themselves were the sole constituents of reality, then reality would not contain freedom; but there are also appearances, and this makes freedom possible in the face of Spinozism.

The difficulty is to understand the sense in which the world of appearances, Nature, is ours, not God's. If we push the thought, it seems there are various ways it can go, and that none of them work for Kant. (i) If appearance is not determined, not even 
indirectly, by things in themselves, then it must be thought to form a sui generis reality beholden to nothing outside it - which is the heretical Fichtean version of transcendental idealism. (ii) Alternatively, if appearances are a sub-realm within the totality of what exists, distinguished simply by their dependence on our forms of sensibility, then (since reality in toto must have a rational character) there must be laws relating them to the whole to which they belong - whereupon appearances are reabsorbed into Spinoza's single substance. (iii) If appearances neither comprise subitems within a comprehensive reality, nor form a (Fichtean) reality of their own, then Kant has failed to show that freedom is anything more than a matter of how practical reason represents the world - and the Spinozist has no need to argue with that; the representation can be explained away as a function of imagination, in Spinoza's sense.

The difficulty we encounter here in determining the meaning of transcendental idealism (more readily visible to us in light of Fichte's redevelopment of Kant's transcendental idealism) is of a general kind and not specific to the theory of freedom: Are appearances merely a part of a larger reality, or are they in some way a reality of their own? But freedom, confronted by Spinozism, is what makes it burst forth as a problem, since in that context - and not in that of empirical knowledge, nor in that of the Third Antinomy, for in neither of those less pressurized and demanding contexts does the empirical/intelligible relation or the constitution of the intelligible need to be specified determinately - we need to be able to spell out the doctrine of transcendental idealism in a way which shows it to underwrite human freedom.

In sum, it seems that the gains that Kant makes by referring human freedom to an intelligible ground are offset by a fundamental problem. That the intelligible grounds of human agency, our intelligible character and exercise of causality of reason, are subject to further intelligible determining conditions is a genuine possibility, which nothing in Kant's system rules out; Kant gives no reason for thinking that the Principle of Sufficient Reason fails to apply to things in themselves. And even if this wholly general worry is regarded as an idle, 'merely theoretical' possibility which the interests of practical reason entitle us to put aside, there are two aggravating considerations which restore its force.

(i) First, the fact of human evil obliges us, as Ulrich, Schmid and Creuzer all point out, to regard the intelligible determination of our intelligible agency as more than a mere conceptual possibility: on the face of it, given Kant's identification of morality with pure practical reason and of the causality of reason with intelligible causality, the 
natural inference to draw when confronted with immoral conduct is that some intelligible factor has impeded our intelligible agency; which gives positive reason for thinking that, in the intelligible domain, our agency is not causally insulated.

To be sure, Kant has an account of evil which precludes the postulation of any such extraneous intelligible factor - his doctrine of radical evil, which says that our intelligible disposition to give preference to incentives of self-love over moral incentives is rooted in an intelligible choice of that very disposition. But the motivation for this doctrine, the reason for affirming it, derives entirely from practical interest, our practice of holding ourselves and one another morally responsible, the integrity of which is here in question; and in any case, Kant himself admits that the postulation of radical evil explains nothing and generates a regress, thus failing to satisfy the Principle of Sufficient Reason.

(ii) Second, Kant leaves us at a loss when it comes to thinking up a configuration for the intelligible realm which would so much as grant a toehold for transcendental freedom. Kant denies that a Leibnizian characterization of the intelligible realm would be consistent with human freedom, and he in any case affirms that the correct (or at any rate, the most warranted) conceptualization of the intelligible realm is not Leibnizian but Spinozistic, which, Kant agrees, destroys human freedom directly. Kant signals his acceptance that the question of how things in themselves are configured has logical implications for the existence of human freedom when he accepts that the threat of Spinozism needs to be met - which he seeks to do by invoking transcendental idealism. But this leads to the problem indicated.

The problems of Kant's theory, it can now be suggested, are rooted in his dual component conception of human freedom. Freedom involves both intelligible causality, required to lift human agency out of the empirical causal network, and transcendental spontaneity, required to provide for the dimension of self-conscious self-determination or choice between alternatives. That these do not necessarily cohere is shown by the opposed reconstruals of Kantian freedom in Schmid and Reinhold. The explanation for their coming apart in the interpretation of Kant stems from the fact that he does not tell us which of the two is the more fundamental - which is a condition of the other, and which of the two human freedom ultimately consists in. Is it that we need to have an intelligible identity, in order that we can enjoy transcendental spontaneity, which is what freedom consists in? Or is transcendental spontaneity simply what makes space in the empirical realm for intelligible causality, which is what freedom consists in? What 
Kant of course needs is the identification of intelligible causality and transcendental spontaneity, but he is not in a position to make that identification, because he has allowed the Principle of Sufficient Reason to stand unchallenged as the law of intelligible reality. Ultimately, then, the Principle of Sufficient Reason is what sets intelligible causality and transcendental spontaneity in conflict and upsets Kant's solution to the problem of human freedom.

This, admittedly perfunctory, assessment of Kant's solution to the problem of human freedom is of course contestable. ${ }^{15}$ What matters for what follows, however, is that it corresponds in its essentials to Schelling's estimate of Kant's legacy on the topic.

\section{Schelling's conception of human freedom in the Freiheitsschrift: revising Kant and elevating evil}

Schelling agrees with Kant that intelligible agency provides the key to human freedom, describing this as the great insight of idealism:

It was, indeed, idealism which first raised the doctrine of freedom into that realm in which it alone is comprehensible. According to idealism, the intelligible being of every thing and especially of man is outside all causal connectedness as it is outside or above all time [...] Free action follows immediately from the intelligible aspect of man. (FS, 383-384)

Schelling also follows Kant in denying that human freedom consists in the bare undetermined power of choice postulated by Reinhold ('equilibrium of choice', Gleichgewicht, as Schelling calls it):

For the usual concept of freedom, according to which freedom is posited as a wholly undetermined capacity to will either one of two contradictory opposites, without determining reasons but simply because it is willed [...] leads to the greatest inconsistencies. $(F S, 382)$

Schelling's departures from Kant begin with his importantly different view of the problem set by evil and its role in relation to freedom. Schelling holds that there must be - for the sake of freedom - some sense in which the choice between good and evil is open, some sense in which they are both real options. As he puts it: '[T]he real and vital conception of freedom is that it is a possibility of good and evil' (FS, 352), 'a vital 
positive power for good and evil' ( $F S, 354)$; '[if] the reality of evil [is] in some way denied, then the real concept of freedom vanishes' $(F S, 353) .{ }^{16}$

Reinhold's postulation of a power intrinsically indifferent to moral distinction might seem to acknowledge but in fact it precludes this condition (FS, 354). It fails to capture the way in which the field of freedom is morally polarized; and so too does Kant's merely negative understanding of choice (rendering Kant's conception of freedom merely 'formal', as Schelling puts $i^{17}$ ). What is required for a solution to the problem of evil, then, is that its ground within the agent be identified in positive terms and in such a way that we grasp the 'pull' of evil.

From this we see that an account of evil is required by Kant and Schelling for quite different reasons. For Kant, it is needed in order that we should be able to impute immoral actions to agents, that is, in order to resolve the puzzle that reason (and hence also freedom) is exercised even in violations of the moral law. For Schelling, it is required in order to give reality to freedom - a proposition which Kant would not accept. For Kant, the reality of freedom is given through the moral law alone. To be sure, the existence of evil follows from this indirectly, as a corollary, since, if we were not capable of departing from the moral law, then that law could not appear to us in the distinctive modality of a Sollen, which is the ground of our knowledge of freedom. Evil is therefore for Kant a negative, indirect condition of human freedom which does not belong directly to its very concept - as it does for Schelling.

This difference concerning its theoretical role entails a difference of view concerning what a theory of evil needs to provide. Both Kant and Schelling hold that the existence of evil requires us to locate within the agent a non-empirical ground of the will's non-conformity to the moral law - for both, evil must have an intelligible locus; both deny that evil is a direct function of the empirical nature in us. ${ }^{18}$ But for Kant, this obliges us only to construct a representation of the ground of evil that sustains the moral imputability of immoral actions. For Schelling, the account must explain evil in the considerably more substantial sense of making it intelligible that we are drawn to it, a datum for which inclination provides no explanation. This explains why Schelling cannot simply take over Kant's theory of radical evil: whether or not Kant's theory is in its own terms coherent, it does not do the work Schelling thinks is needed. ${ }^{19}$

The second and equally striking departure from Kant is Schelling's all-out identification of human freedom with intelligible necessity: 
The intelligible being [of man] can, as certainly as it acts freely and absolutely, just as certainly act only in accordance with its own inner nature; or action can follow from within only in accordance with the law of identity and with absolute necessity, which alone is also absolute freedom. $(F S, 384)$

This immediately raises two questions: Can this modification of Kant be motivated from within the theory of freedom, or does it simply reflect Schelling's general metaphysical differences from Kant, his move from subjective to absolute idealism? And if this is Schelling's view, has he not thereby embraced the intelligible fatalism which Kant sought to avoid (and with good reason)?

Schelling describes his identification of freedom with absolute necessity as a direct inference, not from the Kantian concept of freedom in Kant's own words, but 'as we believe [...] it would have to be expressed in order to be comprehensible' $(F S, 384)$. Schelling therefore believes his innovation to be motivated from within the Kantian theory of freedom. Why does he think this?

If we take into account the all-or-nothing character of the predicament of human freedom as Kant defines it - either Spinozism or transcendental idealism - and the difficulty that, I argued, arises for Kant's transcendental idealism, then we can see how Schelling's modification of Kant can appear unavoidable, once it has been accepted that freedom requires an intelligible grounding. I cited two options concerning the interpretation of transcendental idealism. If the first, Fichtean option represents a dead end, as Schelling believes (for reasons relating to general metaphysics: he considers the Wissenschaftslehre to provide only and at most one, subject-based component of the system of philosophy), then that just leaves the second, the Spinozistic. This looks to destroy freedom so long as containment within God has the character of annihilation of individuality. Schelling is of course aware of this charge levelled against Spinoza stemming from Leibniz but restated most recently and forcibly by Jacobi, in the form of a charge of global nihilism - and acknowledges that it has some basis. But, Schelling argues, Jacobi has misidentified the source of the threat: it is not Spinozism's monism, or pantheism, that is potentially nihilistic, but the 'lifelessness' of Spinoza's substance and the correspondingly mechanistic character of Spinoza's world-order, features which Schelling regards as separable from Spinozistic monism per se. So if, as Schelling believes, the Spinozistic system can be recast, 'spiritualized', then the world qua totality of things in themselves can be reconceived in a way that grounds rather than extinguishes individuality. ${ }^{20}$ If so, then the right strategy, in fact the only way forward 
from Kant's transcendental idealism, is to make provision for human freedom by virtue of the individual's existence within God, whose intrinsic freedom man inherits by derivation: 'Since freedom is unthinkable in opposition to omnipotence, is there any other escape from this argument than to say that man is not outside, but rather in, God and that his activity belongs to the life of God?' (FS, 339).

As regards the second question raised by Schelling's identification of freedom with absolute necessity - the issue of intelligible fatalism - Schelling again does not consider that he has broken with Kant, and again it can be seen why he thinks this.

At first glance it may seem that Schelling with his talk of 'inner necessity' has reverted to the Leibnizian automaton spirituale derided by Kant. But Schelling explains why this is not the case. The non-empirical determination and 'absolute necessity' that Schelling postulates just $i s$, he insists, self-determination, for the reason that the intelligible ground of free agency itself consists in a doing:

[1]ndividual action results from the inner necessity of a free being and, accordingly, from necessity itself [...] But what then is this inner necessity of the being itself? Here lies the point at which necessity and freedom must be unified if they are at all capable of unification. Were this being a dead sort of Being [ein totes Sein] and a merely given one with respect to man, then, because all action resulting from it could do so only with necessity, responsibility [Zurechnungsfähigkeit] and all freedom would be abolished. But precisely this inner necessity is itself freedom; the essence of man is fundamentally his own act; necessity and freedom are in one another as one being [Ein Wesen] that appears as one or the other only when considered from different sides, in itself freedom, formally necessity. The I, says Fichte, is its own act; consciousness is self-positing - but the I is nothing different from this self-positing, rather it is precisely self-positing itself. (FS, 384-385)

Here Schelling says, invoking Fichte, that the intelligible ground of freedom is not 'a dead sort of Being [ein totes Sein]', 'a merely given one with respect to man'; rather 'it is real self-positing', 'a primal and fundamental willing, which makes itself into something and is the ground of all ways of being [Wesenheit]'. Intelligible fatalism 'predestinarianism' as Schelling calls it - is avoided by locating the ground of freedom in a deed and not in a prior existing spiritual substance. The Kantian element of spontaneity and transcendental freedom is conserved in Schelling's Fichteanized version of the doctrine of intelligible selfhood, in so far as the 'I do-' is contained within the act which I am. 
The solution to the problem of intelligible fatalism, according to Schelling, is therefore to reject the assumption that the self-determining agency of the agent is anything separate from the agent's intelligible character: this distinction - which is maintained in Kant, and reflected in the opposition of Schmid's and Reinhold's respective reconstructions of Kantian freedom - is held to vanish. And since Schelling, as a critic of Fichte's idealism, cannot invoke the Wissenschaftslehre as the basis for his identification of the self with a deed, he will have to show that his overhauled Spinozism makes room for that notion.

The task bequeathed by Kant to Schelling, shaping Schelling's redevelopment of Spinoza, includes therefore the following three elements. First, Kant's theory of radical evil must be overhauled, since it fails to provide for the reality of evil in the strong sense required by Schelling. Second, if an appeal to the intelligible is to help with the problem of human freedom, and if the human agent cannot be separated off from the totality of existence by means of transcendental idealism in the way Kant proposes, then it must be shown that this totality is of a kind capable of containing free subjects and endowing them with freedom - something that Spinoza did not do (to that extent justifying Kant's rejection of Spinozism). Third, Kant's difficulty in uniting intelligible character with transcendental spontaneity must be resolved.

\section{A problem for Schelling's Spinozism: whence the finite?}

To these a fourth element must be added which, though not on the explicit agenda of the Freiheitsschrift, is undoubtedly on Schelling's mind in 1809, and it will be important for my reconstruction of his strategy. This is the problem of the derivation of the finite from the infinite - the question, which Schelling had wrestled with in the course of his attempt to formulate a Spinozistic post-Kantian idealism from 1801 to 1804, of how there can be a world of finite things 'in addition to' the absolute (so to speak). ${ }^{21}$

Karl August Eschenmayer, a fellow traveller of Schelling's Naturphilosophie who however entertained misgivings about his Identity Philosophy, emphasized the importance of this question in his 1803 Die Philosophie in ihrem Übergange zur Nichtphilosophie, suggesting that it was decisive for the alternatives of either a wissenschaftlich (Schelling) or a trans-rational glaubensphilosophisch (Eschenmayer) solution to the problem of the absolute. ${ }^{22}$ The question had been treated previously by Schelling himself on several occasions. In the 'Allgemeine Deduktion' of 1800, 
Schelling answered the question of how something finite and real can proceed from the infinite, by appeal to an infinite striving of nature to return to the original identity out of which it was torn by an original division - which he however leaves unexplained. ${ }^{23}$ In the 1801 Darstellung the question was again raised and this time answered in a complex twofold manner, by on the one hand rejecting its presupposition 'that absolute identity has actually stepped beyond itself', and on the other hand relativizing the separation of individual being from the absolute to reflection which has already withdrawn and isolated itself from the absolute centre. ${ }^{24}$ In Bruno (1802) Schelling employed a closely similar if not the same strategy, again insisting on the containment of the finite within the eternal, and referring the separateness of the finite to the perspective of the finite. ${ }^{25}$ Now the question raised by the Darstellung-Bruno solution is whether it reduces the reality of the finite to a matter of representation. Does the existence of the finite consist in nothing more than the mere (mis)representation of its existence? Schelling's answer is not clear: the finite actualizes, he says, a possibility for viewing (or 'positing') itself as separated, a possibility which is supplied for it by the absolute. Whether this allows the finite to exist in any sense beyond representation - and therefore, whether the 'actualization' or self-positing-as-finite yields anything sufficiently robust to deflect the nihilism charge - is uncertain. Equally uncertain is how the absolute, conceived as absolute identity and absolute reason, can bestow on its modes or 'contents' even the mere idea of separate existence, or leave room for its formation, as is presumably required for the relevant self-positing, let alone endow an entity with the power of actualizing the idea. This is the gravamen of Eschenmayer's objection. Schelling's reply to Eschenmayer in Philosophie und Religion (1804) is again not free from ambiguity. Schelling declares abruptly that there is no continuous transition to the finite, which he now describes as a result of the Fall, Abfall, whereby the world, as the other (Gegenbild) of the absolute, rests not on the absolute's processing out from itself but on the finite's falling away from it. ${ }^{26}$ Doubts remain. Philosophie und Religion may be read either as reiterating, in a new vocabulary, the account given in the Darstellung, or as propounding a new doctrine. If the Abfall is indeed a new proposal, then it has not been made clear why it counts as a full solution in a way that the 'original division' adduced in 1800 and the perspectival account of the Darstellung and Bruno do not - if only because the doctrine of Abfall still seems exactly poised between rejecting the question and attempting to answer it. 
This problem may be viewed as the successor in Schelling to the problem confronting Kant's transcendental idealism. Kant's problem of granting appearances sufficient autonomy to make freedom possible, without allowing them to form a sui generis reality displacing things in themselves, becomes in Schelling the task of balancing the absolute's claim to reality with that of finite entities; the issue is again one of ontological competition at a wholly general metaphysical level, precipitated and made acute by its implications for human freedom. And here Kant's defenders may reasonably object that Schelling's Spinozistic turn, in failing to rationalize the existence of the world as a site of finite agency without invoking a duality of incommensurable perspectives, has not delivered what it promised: the difficulties of transcendental idealism have simply reappeared in a new form, in confirmation of the Kantian doctrine that claims to cognition of the unconditioned, even when not caught in contradictions, are necessarily futile in relation to the purposes of human reason.

It would seem therefore that relocating human freedom in the context of a new post-Kantian and post-Spinozistic metaphysics requires more to be said concerning the problem of deriving the finite. In the Freiheitsschrift Schelling implies that, aside from the problem of freedom and evil which has still to be dealt with, all is well with the system of idealism, suggesting perhaps that he takes himself to have solved the problem in his 1804 Philosophie und Religion. However that may be - that is, whether or not the 1804 account is adequate, and whatever Schelling thinks about it - it is also true, I will argue, that the Freiheitsschrift offers a different solution to the problem of the finite, and one which is more convincing.

\section{The metaphysics of the Freiheitsschrift: theogony and the creation of free beings}

We have seen what form the solution must take, but what is its content? Here is an extremely compressed statement of the metaphysics of the Freiheitsschrift. It draws off Jakob Böhme and Plotinus, and takes the shape of a theogony:

Since nothing is prior to, or outside of [außer], God, he must have the ground of his existence [Grund seiner Existenz] in himself. All philosophies say this; but they speak of this ground as of a mere concept without making it into something real [reell] and actual [wirklich]. This ground of his existence, which God has in himself, is not God considered absolutely, that is, in so far as he exists; for it is only the ground of his existence. It is nature - in God, a being indeed 
inseparable, yet still distinct, from him. [...] If we want to bring this way of being closer to us in human terms, we can say: it is the yearning [Sehnsucht] the eternal One feels to give birth to itself. The yearning is not the One itself but is after all co-eternal with it. The yearning wants to give birth to God, that is, unfathomable unity, but in this respect there is not yet unity in the yearning itself. Hence, it is, considered for itself, also will; but will in which there is no understanding [...] This is the incomprehensible base of reality in things, the indivisible remainder, that which with the greatest exertion cannot be resolved in understanding but rather remains eternally in the ground. (FS, 357-360)

Schelling starts with a distinction, 'the distinction between being in so far as it exists [dem Wesen,

sofern es existirt] and being in so far as it is merely the ground of existence [dem Wesen, sofern es bloß Grund von Existenz ist]' (FS, 357), which he says must apply to all things - God included. So with respect to God we must distinguish his existence as God, from the ground of his existence - which, Schelling says, should be conceived as indeterminate objectless will or as longing or yearning. The implicit object of this primal will or longing, the final cause which draws it out of itself, is understanding and self-consciousness, knowing itself as something existing, a formed unity. When this development is complete, we have God as God. The ground of God's existence has not however been consumed or sublated in this process - Schelling refers to it as an 'indivisible remainder', and it abides as the ground which continues to give God being as God. God has therefore an internal complexity, comprehending two principles, one rational and one pre-rational; principles of light and darkness, as Schelling calls them.

Were Schelling a theist, the next step would be the creation of man and world, as a separate and further matter; which would involve God's exercising will and judgement, in the way that Leibniz supposes, and which, Schelling believes, renders the problems of evil and human freedom insoluble. But on Schelling's pantheistic account, man and the world result not from a separate act of creation but come to be in the course of God's self-genesis - their existence is implicated in God's becoming, and God does not come to completion without man and world. And this implies - what is crucial for Schelling's theory of evil - that the same duality of principles that makes up the being of God also makes up the being of man (and other creatures): the distinction of existence and ground of existence, principles of light and darkness, applies to man as it does to God - but with the essential difference that while these principles are inseparable in God (who is a necessary unity) they are separable in man. And this yields the possibility 
of evil: a condition in which the principles have come apart, the non-rational principle of darkness claiming for itself an independent existence. Evil consists in striving to give oneself, wilfully claiming for oneself, a selfhood independent of God. The locus of evil thus lies for Schelling, as it does for Kant, in the disposition of the individual subject, and the determination of this disposition, the individual's decision for either good or evil, takes place (as per the Fichtean conception of the being of the self as that of an act) at the point where the individual comes into existence, a point not in time but eternity.

Man is in the initial creation, as shown, an undecided being - (which may be portrayed mythically as a condition of innocence that precedes this life and as an initial blessedness) - only man himself can decide. But this decision cannot occur within time; it occurs outside of all time and, hence, together with the first creation (though as a deed distinct from creation). Man, even if born in time, is indeed created into the beginning of the creation (the centrum). The act, whereby his life is determined in time, does not itself belong to time but rather to eternity: it also does not temporally precede life but goes through time (unhampered by it) as an act which is eternal by nature. Through this act the life of man reaches to the beginning of creation; hence, through it man is outside the created, being free and eternal beginning itself. As incomprehensible as this idea may appear to conventional ways of thinking, there is indeed in each man a feeling in accord with it as if he had been what he is already from all eternity and had by no means become so first in time. (FS, 385-386)

\section{The strategy of the Freiheitsschrift: analysis and interpretation}

The preceding is a very compressed and incomplete précis, in which two compact passages from Schelling have been asked to assume the main burden, but it supplies enough for us to now be able to grasp how the Freiheitsschrift offers a complex solution to the four problems identified as its targets. I argued that Schelling aims to (1) identify the positive ground of evil, (2) explain how free individuality can reside within God, (3) explain how intelligible necessity can coincide with spontaneous self-determination, and (4) account for the possibility of the finite world. Schelling takes these apparently independent problems and proceeds to solve them in the manner of simultaneous equations, that is, by cross-referring them to one another. The reality of evil appears to set an insoluble problem, not just to Kant but to all metaphysics, for the reasons that Schelling goes over in the early part of the Freiheitsschrift - in short, because no coherent way of introducing evil into the fabric of being can be conceived (at any rate: 
as philosophers have hitherto conceived being). And the existence of the finite world appears to set an insoluble problem for monism, so long as the absolute is conceived as an absolute identity - the problem that Schelling's Identity Philosophy had left unresolved. But when the existence of evil and the existence of the finite world are taken together as interconnected primary data for metaphysical speculation, the basis is laid for the account we have seen Schelling give of God's genesis and our genesis inand-with God, through which the problems associated with each are dissolved. $(\operatorname{Re} 4:)$ We discover in human evil the reason why there is a world of finite things, in so far as the structure of free human personality - its unity of opposing principles - articulates a ground which makes the existence of the finite world intelligible. We now understand why the problem of the finite world proved intractable for the system of absolute identity, forcing it into equivocation, and why the doctrine of Abfall in Philosophie und Religion - when read in light of, and as anticipating, the standpoint of the Freiheitsschrift - counts as a solution in a way that Schelling's early proposals do not. (Re 1:) This ground ${ }^{27}$ entails the reality and necessity of evil, without either making God the root of evil or resorting to Gnosticism. ${ }^{28}$ (Re 3:) If the genesis of the human subject out of God recapitulates, indeed sub-coincides with, God's self-genesis, then the same identity of being and acting, of intelligible character and spontaneity, as obtains in God can and must find itself reproduced in the human individual. The problematic duality in Kant's conception of freedom, reflected in the Schmid-Reinhold opposition, is thereby eliminated. At the same time, Schelling has protected intelligible causality from intelligible fatalism, without invoking an indeterministic power of choice: ${ }^{29}$ because man is created with and in God's self-creation, and is not the effect of an act of creation as per Leibniz, we do not stand under, we are not subject to, God's determination; instead we partake of God's own dynamic and creative, self-individualized nature. (Re 2:) It is thereby also explained how free individuality can reside within God, answering squarely Jacobi's charge of nihilism.

Assuming this to be a correct analysis of Schelling's strategy, let me now say how I think it is ultimately grounded. The Freiheitsschrift may be interpreted as taking the structure of free human personality - rather than merely the structure of theoretical and practical self-consciousness, which does indeed belong to its core but which does not constitute it as a whole - as the guiding principle for the construction of metaphysics. ${ }^{30}$ The structure which Schelling finds in man and imputes to God is that of conditioned autonomy or what Schelling calls 'derivative absoluteness', derivirte 
Absolutheit (FS, 347), and this is what his asymmetric dyad of existence and ground-ofexistence is intended to elucidate. Schelling arrives at this conception in the Freiheitsschrift ${ }^{31}$ not by any epistemological or directly theoretical metaphysical route but by extrapolation from what Kant calls the practical point of view. The extrapolations are not however mere 'practical cognitions' in the sense of postulates validated by their function for practical reason, such as those which comprise Kant's moral theology. ${ }^{32}$ Schelling's argument from from the practical sphere to the theoretical should instead be viewed in the terms proposed by Paul Franks as a general way of understanding the development of German Idealism. Franks argues that Kant's deduction of the moral law in the second Critique, his account of the Fact of Reason, provides a template for German Idealism, which adopts the strategy of deducing an ontic ground - in German Idealism: the actuality of the intelligible ground of the world, the ens realissimum from an epistemic ground, our consciousness of the normativity of pure reason. ${ }^{33} \mathrm{In}$ these terms, what may be said of Schelling is that he in the Freiheitsschrift repeats the exercise of the second Critique on an amplified and modified basis: whereas Kant in the Deduction restricts the data to the single, normatively positive fact of respect for the moral law - as befits his aim to justify the moral law - and defers consideration of the ground of evil to another, secondary context, Schelling admits evil into the primary data. Now evil is not the absence, but the inverse or negation of normativity. So in Schelling what we work out from, the epistemic ground which leads to an ontic ground, is not simple one-sided awareness of obligation qua respect for the moral law, but complex two-sided awareness of, on the one side, respect for the moral law, and on the other side, the non-necessity, grounded in one's will, of determining oneself in conformity with the moral law consequent upon one's own repudiation of it. On this basis Kant's conception of human freedom is revised, while Kantian radical evil is transposed down a level: it is no longer merely a theoretical posit with auxiliary regulative significance, but has become part of the 'factual' (in Kant's sense) normative given. Kant's Fact of Reason thus becomes in Schelling the double fact of reason and correlative unreason, with all of the resulting metaphysical differences. The derivation of general metaphysics from the practical point of view is based, therefore, on practical cognition in Kant's primary sense of knowledge of our own intelligible causality.

The feature of the opposition of good and evil that allows it to play a privileged role in metaphysical construction is the asymmetry regarding their respective relations to Reason: as Kant's analysis reveals, good is what there must be reason to do, while 
evil is what there cannot be reason to do; the choice between good and evil is thus no choice at all; and yet we do choose between them, we are presented with a choice between them; meaning that the boundary of the space of reasons does not determine the limit of what we are acquainted with as having reality. The pair good/evil, one of which lies inside the space of reasons and the other outside, the two nonetheless being inseparably united, furnishes the conceptual form employed by Schelling to grasp being as such, the duality of Grund and Existenz: being as such is thought as having the shape and character of the opposition of good and evil. It follows that, since the opposition of good and evil is an opposition of what is reason to what is not reason, Schelling has pushed speculative thought beyond the Principle of Sufficient Reason - meaning that the principle which, in its unrestricted form, posed the original threat to human freedom, and which Kant aimed to merely suspend with the aid of transcendental idealism, has finally been disarmed. Ultimately this is achieved through Schelling's reconception of human freedom as encompassing good and evil, whereby it encompasses the negation of the Principle of Sufficient Reason (and is therefore immunized against objections to human freedom deploying that principle). ${ }^{34}$

Let me try to make clearer my suggestion that the opposition of good and evil in some way exhibits, gives oblique access to, the dislocation or disunity within being which Schelling expresses in terms of his distinction of existence from its ground. This distinction, on which the whole argument of the Freiheitsschrift turns, involves a modification of our understanding of ontological talk, and is intended as revisionary; as if to underline its revisionary character, Schelling intimates that the ground of existence is tainted with non-being, that is, cannot itself be said unequivocally to exist or have being. Schelling's thesis concerning being is therefore not simply that it has fundamentally different types, on a par with the distinction of Nature and Spirit, or of the potential and the actual: it is that there is a complexity and conceptual opacity in being which is concealed in plain ontological assertion, such that the notion of something's simply existing or having existence, simply 'being the case', is defective. The assumption that existence as such is transparent and non-complex is present in, but not confined to, ordinary understanding: it extends to the highest speculative systems, Spinoza's and Hegel's included. Hegel says in the Encyclopaedia Logic that, although we cannot stop with mere being, and although being is not firm and ultimate and will be seen to turn dialectically into its opposite, it is nonetheless absurd to regard any content of consciousness as 'beside' and 'outside' being, or as 'additional' to it. ${ }^{35}$ This assumption 
of absolute primitive simplicity, which allows Hegel to set 'pure being' (the 'pure thought' of what is 'quite simply being', eben nur das Sein ist) at the beginning of his Logic, is what Schelling must be taken to be challenging. The rival position articulated in the Freiheitsschrift is that the non-simplicity of being is attested in our knowledge of good and evil, and of ourselves as entities for whom both are possibilities - something which would not be possible if existence were the simple thing that it is taken to be in the ontologies of common sense, Spinoza, and Hegel. In sum, Schelling's argument is that, if existence were the bare and simple fact that it is naturally and universally taken to be, then it would be impossible for anything to exist with the possibility for good or evil, and since the practical point of view reveals that such a being does exist, existence cannot be simple. Though good and evil are necessarily unified - in so far as both fall within the span of a self's field of decision - the distance that separates them, the degree and kind of their opposition to one another, is too great to be contained within a single domain of 'existing things'. If we are to think both good and evil as having being, as we must, then the ordinary concept of being must be reconfigured.

Can Schelling be said to have explained the existence of evil, freedom, and the finite, in the Freiheitsschrift? Has he made freedom and evil comprehensible in the sense denied by Kant? At one level, it would seem so. What emerges from the enquiry is a unified systematic solution to several problems, according to which God, the world, man, human freedom, and evil, can all be derived from the structure of being. So we have metaphysical explanation in the full and proper sense. And as Schelling emphasizes in the close of the essay, the Freiheitsschrift does the work of a traditional theodicy, supplanting Leibniz: it has been shown that God is as he needs to be, and does all that needs to be done, in order for the highest value to be realized; evil has positive reality, yet all is for the best. Putting it like this, however, misses something important, the very thing that distinguishes the Freiheitsschrift from other treatments of the problem of evil. The crux of Schelling's strategy, I suggested, lies in repositioning the relevant explananda - freedom and evil - at the outer limit of philosophical understanding, and in showing that this limit cannot be regarded as subjective, a consequence of the limits of our cognitive powers, but must be regarded as objective, as marking the point where being extends beyond reason. If so, then Schelling's aim cannot be to explain freedom and evil, for what he shows is that freedom and evil are necessarily and in themselves ungrounded. The aim must be, instead, to exhibit freedom and evil as ultimate ontological facts, features of being that could not be consequences 
of anything more fundamental. Thus one might say that Schelling has eliminated the incomprehensibility of freedom asserted by Kant, but without providing a comprehension of freedom; and, with reference to the problem of evil, that what Schelling has done is to allow the question, Why is there evil?, to receive the answer, For no reason - he has supplied conditions under which this counts as the complete and correct answer. The Freiheitsschrift may do the work of the Theodicy in exonerating God and reconciling us to existence, but the means employed are the reverse of Leibniz's.

I referred at the outset to the issue of Schelling's place in the German Idealist development. It is not hard to see why it may be thought, in view of the Böhmeinfluenced story of God's self-genesis which stands at its centre, that the Freiheitsschrift should be interpreted not as yet more metaphysics, but rather as implying the abandonment altogether of metaphysics conceived as a task of explanation, and as anticipating later philosophical developments - Kierkegaard, Heidegger, Schopenhauer to some extent - which make that theme explicit. ${ }^{36}$ The account I have offered does not, however, support this assessment, in so far as (I hope to have shown) the doctrinal philosophical content of the Freiheitsschrift can be arrived at by continuous (constructive, yet warranted) steps from a Kantian starting point. That Schelling must be regarded as revising the ground-consequent form of metaphysical explanation does not mean he is abandoning it; that the Freiheitsschrift affirms the reality of Unreason in some sense does not entail either a leap out of Reason or its delegitimation, since what Schelling means to do in it is precisely to plot the relation of 'Unreason' to Reason by consideration of what metaphysical explanation requires. ${ }^{37}$ It is true nonetheless that a clearer view is needed of the status the theogony, which might be interpreted not as a metaphysics meant to replace the Identity Philosophy after it has been pushed as far as it can go, but instead as a mythological presentation of a philosophical insight which receives its officially correct formulation in logical theory. ${ }^{38}$ This is a difficult question, concerning which Schelling perhaps did not have clear and definite views in 1809, and which the Weltalter texts do not fully settle either, eventually finding itself overtaken by his distinction of 'negative' and 'positive' philosophies. The Freiheitsschrift thus looks forward in Schelling's development, at the same time offering a resolution of the aporiae of his early work. ${ }^{39}$ 


\section{References}

Baader, Franz von, 'Über den Affekt der Bewunderung und der Ehrfurcht' (1804), in Gesammelte Schriften zur philosophischen Erkenntnisswissenschaft als speculative Logik, ed. Franz Hoffmann (Leipzig: Bethmann, 1851).

Creuzer, Christian Andreas Leonhard, Skeptische Betrachtungen über die Freiheit des Willens: mit Hinsicht auf die neuesten Theorien über dieselbe (Giessen: Heyer, 1793). Dews, Peter, The Idea of Evil (Oxford: Blackwell, 2008).

Eschenmayer, Karl August, Die Philosophie in ihrem Übergange zur Nichtphilosophie (Erlangen: Walter, 1803).

Franks, Paul, All or Nothing: Systematicity, Transcendental Arguments, and Skepticism in German Idealism (Cambridge, MA: Harvard University Press, 2005).

Hegel, Georg Wilhelm Friedrich, The Encyclopaedia Logic (with the Zusätze) (1817), trans. and ed. T. F. Geraets, W. A. Suchting and H. S. Harris (Indianapolis: Hackett, 1991).

Heidegger, Martin, Schelling's Treatise on the Essence of Human Freedom (1936), trans. Joan Stambaugh (Athens: Ohio University Press, 1984).

Heidegger, Martin, 'The Principle of Reason' (1956), in The Principle of Reason, trans. Reginald Lilly (Bloomington: Indiana University Press, 1991), pp. 117-129.

Kant, Immanuel, Religion Within the Boundaries of Mere Reason (1793), in Kant, Religion and Rational Theology, trans. and ed. Allen W. Wood and George di Giovanni (Cambridge: Cambridge University Press, 1996).

Kant, Immanuel, Practical Philosophy, trans. and ed. Mary J. Gregor (Cambridge: Cambridge University Press, 1996).

Kosch, Michelle, Freedom and Reason in Kant, Schelling and Kierkegaard (Oxford: Oxford University Press, 2006).

O'Connor, Brian, 'Self-Determination and Responsibility in Schelling's Freiheitsschrift', Studies in Social and Political Thought, 21, 2013, 3-18.

'The Oldest System-Programme of German Idealism' (1796/97[?]), European Journal of Philosophy, 3:2, 1995, 199-200,

Pippin, Robert, 'Heideggerean Postmodernism and Metaphysical Politics', European Journal of Philosophy, 4:1, 1996, 17-37.

Reinhold, Karl Leonhard, 'Erörterung des Begriffes von der Freiheit des Willens', Briefe über die kantische Philosophie, Bd. 2 (Leipzig: Georg Joachim Göschen, 1792). 
Schelling, Friedrich Wilhelm Joseph von, 'Allgemeine Deduktion des dynamischen Prozesses oder der Kategorien der Physik', Zeitschrift für spekulative Physik, Bd. I, 1800 .

Schelling, Friedrich Wilhelm Joseph von, Presentation of my System of Philosophy (1801), trans. Michael G. Vater, in Philosophical Forum, 32:4, 2001, 339-371.

Schelling, Friedrich Wilhelm Joseph von, Philosophie und Religion (1804), in Friedrich Wilhelm Joseph von Schellings sämmtliche Werke, ed. Karl Friedrich August Schelling, Abteiling I, Bd. VI (Stuttgart: Cotta, 1860), pp. 11-70.

Schelling, Friedrich Wilhelm Joseph von, Bruno, or On the Natural and the Divine Principle of Things (1802), trans. and ed. Michael G. Vater (Albany, NY: State University of New York Press, 1984).

Schelling, Friedrich Wilhelm Joseph von (1809), Philosophical Inquiries into the Nature of Human Freedom, trans. James Guttman (LaSalle: Open Court, 1936). Schelling, Friedrich Wilhelm Joseph von (1809), Philosophical Investigations into the Essence of Human Freedom and Matters Connected Therewith, trans. Jeff Love and Johannes Schmidt (Albany, NY: State University of New York Press, 2006).

Schelling, Friedrich Wilhelm Joseph von (1809), Philosophische Untersuchungen über das Wesen der menschlichen Freiheit und die zusammenhängenden Gegenstände (1809), in Friedrich Wilhelm Joseph von Schellings sämmtliche Werke, ed. Karl Friedrich August Schelling, Abteiling I, Bd. VII (Stuttgart: Cotta, 1860), pp. 331-416. Schelling, Friedrich Wilhelm Joseph von, The Ages of the World (1813), trans Judith Norman, in Slavoj Žižek, The Abyss of Freedom/Ages of the World (Ann Arbour: University of Michigan Press, 1997).

Schmid, Carl Christian Erhard, Versuch einer Moralphilosophie (Jena: Crökerschen Buchhandlung, 1790).

Ulrich, Johann August Heinrich, Eleutheriologie, oder über Freiheit und Notwendigkeit. Zum Gebrauch der Vorlesungen in den Michaelsferien (Jena: Crökerschen Buchhandlung, 1788).

Watkins, Eric, and Kimberly Brewer, 'A Difficulty Still Awaits: Kant, Spinoza, and the Threat of Theological Determinism', Kant-Studien, 103, 2012, 163-187. 
1 'The Oldest System-Programme of German Idealism' (1796/97[?]), European Journal of Philosophy, 3:2, 1995, 199-200.

${ }^{2}$ Two English translations are available: Philosophical Inquiries into the Nature of Human Freedom, trans. James Guttman (LaSalle: Open Court, 1936), and Philosophical Investigations into the Essence of Human Freedom and Matters Connected Therewith, trans. Jeff Love and Johannes Schmidt (Albany, NY: State University of New York Press, 2006). Quotations are based on one or the other with occasional modification. References are prefixed ' $F S$ ' followed by the pagination (given in both English editions) of Philosophische Untersuchungen über das Wesen der menschlichen Freiheit und die zusammenhängenden Gegenstände, in Friedrich Wilhelm Joseph von Schellings sämmtliche Werke, ed. Karl Friedrich August Schelling, Abteiling I, Bd. VII, 331-416 (Stuttgart: Cotta, 1860).

3 '[T]his single treatise attains the acme of the metaphysics of German Idealism'; Schelling's Treatise on the Essence of Human Freedom (1936), trans. Joan Stambaugh (Athens: Ohio University Press, 1984), p. 165.

${ }^{4}$ On which topic see Paul Franks, All or Nothing: Systematicity, Transcendental Arguments, and Skepticism in German Idealism (Cambridge, MA: Harvard University Press, 2005).

${ }^{5}$ For a very different take on the Freiheitsschrift but with similar import, see Robert Pippin, 'Heideggerean Postmodernism and Metaphysical Politics', European Journal of Philosophy, 4:1, 1996, 17-37.

${ }^{6}$ Groundwork of the Metaphysics of Morals (1785), 4:458-459, in Immanuel Kant, Practical Philosophy, trans. and ed. Mary J. Gregor (Cambridge: Cambridge University Press, 1996), p. 104.

${ }^{7}$ The argument is given in the Solution to the Third Antinomy in the Critique of Pure Reason (trans. and ed. Paul Guyer and Allen Wood, Cambridge: Cambridge University Press, 1998), A532-537/B560-565: 'if appearances are things in themselves, then freedom cannot be saved', for nature is then the 'determining cause, sufficient in itself, of every occurrence'; while if appearances are no more than 'representations connected according to empirical laws', occurences in nature can be regarded, also, as the effects of extra-natural (intelligible) causes (A536-537/B564-565).

8 'Something must be thought to be present which, along with the existence of reason, determines its causality on appearances and the particular degree of efficacy thereof on each occasion' (Carl Christian Erhard Schmidt, Versuch einer Moralphilosophie (Jena: Crökerschen Buchhandlung, 1790), §255, p. 209). What exactly this 'something' might be (and how it might operate) is left open by the definition of intelligible fatalism, which requires only that it be something other than the agent's exercise of their reason. The difficulty had been indicated earlier by Johann August Heinrich Ulrich: 'All in all I do not see how the question can be avoided: Why is this power [of reason] exercised with respect to some actions and not others? Either something is present which contains the ground of its exercise on one occasion and of its omission on another, or it is not; in the one case, we have necessity, in the other, chance' (Eleutheriologie, oder über Freiheit und Notwendigkeit. Zum Gebrauch der Vorlesungen in den Michaelsferien (Jena: Crökerschen Buchhandlung, 1788), §12, p. 34).

9 'What is positive in freedom consists in the self-activity of the person in volition, a very special form of self-activity which must be distinguished clearly from that of, or that achieved through, reason' (Karl Leonhard Reinhold, 'Erörterung des Begriffes von der Freiheit des Willens', Briefe über die kantische Philosophie, Bd. 2 (Leipzig: Georg Joachim Göschen, 1792), Achter Brief, p. 281).

10 'Free from the laws of sensible nature, we believe ourselves to be above laws in general, without considering that the temporal circumstances which sometimes seem to limit us refer to something intelligible [...] which on particular occasions make is impossible for morality to reveal itself in appearance' (Christian Andreas Leonhard Creuzer, Skeptische Betrachtungen über die Freiheit des Willens: mit Hinsicht auf die neuesten Theorien über dieselbe (Giessen: Heyer, 1793), pp. 198-199). 
${ }^{11}$ The Metaphysics of Morals (1797), 6:226-227, in Kant, Practical Philosophy, pp. 380-381. One very large and much-discussed question which arises here is whether Kant thereby rules out free action in conscious non-conformity with the moral law, making culpable immorality impossible. Interestingly, this is not the vital issue for Schelling in the Freiheitsschrift. If we ask why it is not, then it is (I suggest) because Schelling rightly sees (1) that Kant's claim (i) that attributions of Willkür are conceptually dependent on attributions of capacity-for-Wille, does not imply, as his critics assert, that (ii) each particular action not in accord with Wille is unfree; and (2) that, if an explanation is required for why (i) does not imply (ii), then Kant's doctrine of radical evil supplies the answer (as discussed below; where it will be seen that Schelling has no dispute with Kant concerning the formulation, as opposed to the comprehensiveness, of the merely 'formal' concept of freedom).

${ }^{12}$ Critique of Practical Reason (1788), 5:100-101, in Kant, Practical Philosophy, pp. 220-221.

${ }^{13}$ Ibid, 5:102, p. 221.

${ }^{14}$ Ibid, 5:102, p. 222.

${ }^{15}$ The most obvious scope which remains for Kant's defence will involve removing Kant from the framework of his post-Kantian reception, by lightening the load to be borne by a theory of freedom - contra the terms of the post-Kantian freedom debate, which assumes that (as per the very title of the Freiheitsschrift) there is such a thing as the essence, das Wesen, of human freedom. For a defence of Kant which does not involve lowering the bar, see Eric Watkins and Kimberly Brewer, 'A Difficulty Still Awaits: Kant, Spinoza, and the Threat of Theological Determinism', Kant-Studien, 103, 2012, 163-187.

${ }^{16}$ It is possible that Schelling was influenced by the polarity of mind postulated in Franz von Baader's application of Naturphilosophie to human psychology in his 1804 essay, 'Über den Affekt der Bewunderung und der Ehrfurcht' (republished in Gesammelte Schriften zur philosophischen Erkenntnisswissenschaft als speculative Logik, ed. Franz Hoffmann, Leipzig: Bethmann, 1851).

${ }^{17} \mathrm{FS}, 347,349,351$.

${ }^{18}$ FS, 372, and Kant, Religion Within the Boundaries of Mere Reason (1793), in Kant, Religion and Rational Theology, trans. and ed. Allen W. Wood and George di Giovanni (Cambridge: Cambridge University Press, 1996), 6:34-35, pp. 81-82. Schelling does talk of 'evil inclinations' at $F S, 390$, but these are derivative.

${ }^{19}$ It is not entirely clear what Schelling thinks of Kant's theory of radical evil in the Freiheitsschrift. At FS, 372, having observed that 'to say that the reasonable principle is ineffective in evil [...] explains nothing. For why does it not exert its power?', he notes that the locus of evil shifts to an intelligible 'preference': 'If it [reason] prefers to be ineffective, then the basis of evil is in this preference and not in the world of the senses.' This presumably can be taken to refer to Kant. But Schelling does not say what he thinks of this imputable 'preference' and instead moves on directly to infer the necessity of a 'dual will'. At FS, 388, the notion of a 'transcendental act determining all human existence' is reascribed to Fichte and said to be missing from Kant at least 'in Theorie', i.e., in theoretical philosophy.

${ }^{20} \mathrm{FS}, 340-347$. Schelling here maintains that Kant was wrong to have regarded Spinozism as such opposed to freedom as he, Kant, understood it, i.e. as something 'formal'. The real problem begins, according to Schelling, only when freedom is conceived as requiring evil.

${ }^{21}$ It is notable that what one might think of as two distinct problems posing unequal degrees of difficulty - How, if the infinite is everything, is the finite possible at all? (the marginally easier question), and, How can the finite be derived from the infinite? (the harder) - are not separated out in the discussions that follow. Again see Franks, op. cit.

${ }^{22}$ Karl August Eschenmayer, Die Philosophie in ihrem Übergange zur Nichtphilosophie (Erlangen: Walter, 1803), §§70-78.

23 'Allgemeine Deduktion des dynamischen Prozesses oder der Kategorien der Physik', Zeitschrift für spekulative Physik, Bd. I, 1800, §7.

${ }^{24}$ See $\S \S 12-14$ and $\S \S 26-30$ of Presentation of my System of Philosophy (1801), trans. Michael G. Vater, in Philosophical Forum, 32:4, 2001, 339-371. Individual being qua non-identical with the absolute is not altogether without foundation, and to that extent is not arbitrary: it 
results from a perspectival conversion of the 'quantitative difference' which lies in the absolute. But the conversion itself is arbitrary in the sense of being 'false from the standpoint of reason' (p. 358). The final remark of $\S 30$ (p. 359) suggests that Schelling does not take the question to have been answered fully.

${ }^{25}$ Bruno, or On the Natural and the Divine Principle of Things (1802), trans. and ed. Michael G. Vater (Albany, NY: State University of New York Press, 1984), pp. 149-150, 158-159.

${ }^{26}$ Philosophie und Religion (1804), in Friedrich Wilhelm Joseph von Schellings sämmtliche Werke, ed. Karl Friedrich August Schelling, Abteiling I, Bd. VI (Stuttgart: Cotta, 1860), p. 38.

${ }^{27}$ And not finitude as such: $F S, 372$.

${ }^{28}$ The latter option is dismissed at $F S, 354$.

${ }^{29}$ This must be immediately qualified as open to dispute. The complex issue of how the self's original intelligible act-being is to be characterized with respect to determinism and indeterminism, with some commentators arguing that Schelling reinvokes indeterminism at this point, can for present purposes be set aside. On the issue see Michelle Kosch, Freedom and Reason in Kant, Schelling and Kierkegaard (Oxford: Oxford University Press, 2006), Ch. 4, and Brian O'Connor, 'Self-Determination and Responsibility in Schelling's Freiheitsschrift', Studies in Social and Political Thought, 21, 2013, 3-18. I suggest that, at the level in question, it is hard to see how the distinction can have meaningful application; at any rate it cannot turn any of the wheels intended, or generate any of the difficulties that arise, when indeterminism is affirmed or rejected at sub-absolute levels.

${ }^{30}$ See also the 1813 The Ages of the World, trans Judith Norman, in Slavoj Žižek, The Abyss of Freedom/Ages of the World (Ann Arbour: University of Michigan Press, 1997), pp. 114-117, 128.

${ }^{31}$ This qualification is important, since the distinction can be introduced in other ways, as Schelling does in the Weltalter texts.

${ }^{32}$ Schelling rejects the strategy, which he came to see as vitiating Fichte's philosophy, of referring the truth of a metaphysical system to its practical role in facilitating the moral determination of the will.

${ }^{33}$ Franks, op. cit., Ch. 5.

${ }^{34}$ What Schelling says concerning PSR in the Freiheitsschrift is just that the idealization of Spinozism allows it to be reinterpreted as a creative principle $(F S, 345-346)$, but this part of his discussion precedes the exposition of the correct concept of freedom.

${ }^{35}$ The Encyclopaedia Logic (with the Zusätze) (1817), trans. and ed. T. F. Geraets, W. A. Suchting and H. S. Harris (Indianapolis: Hackett, 1991), §86, Zusatz 2, p. 139.

${ }^{36}$ As Peter Dews notes in The Idea of Evil (Oxford: Blackwell, 2008), p. 71, Schelling's turn to 'quasi-theological', 'figurative, anthropomorphic discourse' in the Freiheitsschrift is at odds with the rationalism of modernity to which Fichte remains committed.

${ }^{37}$ Heidegger was therefore right, in his own terms, to maintain reservations about Schelling's position (op. cit., pp. 123-125, 175, 193). Heidegger's critical discussion of German Idealism in his Beiträge, composed shortly afterwards, does not single out the Freiheitsschrift for exemption. The route that I am suggesting Schelling does not take is the one that, I think, Heidegger does take in his 1956 address, 'The Principle of Reason', in The Principle of Reason, trans. Reginald Lilly (Bloomington: Indiana University Press, 1991), pp. 117-129. The complex engagement of the Freiheitsschrift with the intensely difficult notion of necessary limits of reason explains the high interest which it hold for contemporary philosophers such as Žižek. ${ }^{38}$ Recalling the mythological rendering of ideas projected in the 'Oldest System-Programme'. ${ }^{39}$ I am grateful to audiences at the Institute of Philosophy at the University of London, Temple University, University College Dublin, the University of Leiden, the University of Tübingen, and the University of Essex, where earlier versions of this paper were presented, and in particular for the helpful comments of Peter Dews, Markus Gabriel, Ken Gemes, Wayne Martin, Brian O'Connor, Julia Peters, Ulrich Schlösser, Herman Siemens, and Eric Watkins. I also wish to thank two anonymous referees for the $B J H P$ for their extremely helpful comments. 